\title{
Pemanfaatan mading dan website dalam membentuk sikap antikorupsi siswa di kota Kupang
}

\author{
Atwar Bajari', dan Uud Wahyudin ${ }^{2}$ \\ 1,2Universitas Padjadjaran, Bandung, Indonesia
}

\begin{abstract}
ABSTRAK
Peningkatan angka kejahatan korupsi di Indonesia sangat menghawatirkan. Namun demikian peran media lebih banyak memberikan perhatian pada pemberitaan dan pendalaman kasus, serta jarang sekali berperan sebagai media edukasi dan peningkatan literasi. Padahal, generasi muda membutuhkan edukasi tentang bahaya korupsi dan pembentukan sikap anti korupsi. Penelitian ini berusaha merancang media alternatif website dan mading dengan jenis pesan informatif dan persuasif tentang bahaya korupsi, yang tidak dilakukan oleh media massa. Eksperimen dua media dengan dua jenis pesan dilakukan untuk mengetahui perubahan dan pembentukan sikap anti korupsi dari anak-anak yang menjadi objek penelitian. Metode penelitian yang digunakan adalah eksperimen $4 \times 3$ dengan jumlah anggota pada setiap kelompok adalah 15 orang. Pengukuran dilakukan dua kali yakni pre-test dan post-test untuk mengukur perubahan yang terjadi dengan melihat perbedaan dua rata-rata pengukuran. Pengolahan data menggunakan analisis deskriptif dan analisis statistik inferensial menggunakan uji $t$ dan uji perbandingan kelompok Kuskal-Wallis $(\mathrm{H})$ untuk mengetahui desain kelompok terunggul. Tingkat kepercayaan untuk setiap pengujian pada (p) 0,05. Penelitian dilakukan pada SMA Negeri di Kota Kupang, Nusa Tenggara Timur. Provinsi NTT memiliki angka kasus korupsi tinggi. Hasil penelitian menunjukkan bahwa mading lebih mampu membentuk sikap anti korupsi dibandingkan website dan jenis pesan persuasif memiliki pengaruh berbeda secara signifikan dibandingkan jenis pesan informatif dalam mempengaruhi sikap anti korupsi. Kemudian kombinasi mading dengan pesan persuasif memberikan skor rata-rata sikap anti korupsi lebih tinggi dibandingkan mading dengan pesan informatif, website dengan pesan persuasif dan website dengan pesan informatif.
\end{abstract}

Kata-kata Kunci: antikorupsi; eksperimen; mading; pesan persuasif; website

\section{Utilization of mading and website on anticorruption attitude of students in Kupang city}

\begin{abstract}
It has been a major concern on how corruption crimes increase each day in Indonesia. Media should not only provide coverage and deepening corruption cases, but also educate media literacy and socialize the dangers of corruption for the younger generation. Media should also be a platform to construct an anticorruption attitude. The study attempts to design alternative media Websites and Wall Magazine with a design of informative and persuasive messages about the dangers of corruption. The research conducted an experiment in two media with two designed messages. The purpose was to find out the anti-corruption attitude changes in children. The research method used was a $4 \times 3$ experiment with 15 members in each group. Measurements were made twice namely pre-test and post-test to find out the changes that occurred by looking at the difference in the two measurement averages. Data processing used descriptive analysis and inferential statistics with t-test and comparison test of Kuskal-Wallis group (H) to find out the best group design. The level of reliance for each was at (p) 0.05. The study was conducted at Senior High Public School Kupang, East Nusa Tenggara (NTT), where NTT Province is one of the highest provinces of corruption cases. The results showed that Wall Magazine was able to form better anti-corruption attitudes than Websites. The design of persuasive messages had a significantly different effect than the informative message design in influencing anti-corruption attitudes. The combination of Wall Magazine with persuasive messages gave an average score of anti-corruption attitudes higher than Wall Magazine with informative messages, Websites with persuasive messages and Websites with informative messages.
\end{abstract}

Keywords: digital literacy; digital media; media content; positive content; social media

Korespondensi: Dr. Atwar Bajari, M.Si. Fakultas Ilmu Komunikasi Universitas Padjadjaran. Bandung, Jawa Barat, Indonesia.Email: atwar.bajari@unpad.ac.id 


\section{PENDAHULUAN}

Krisis bernegara mulai muncul di Indonesia saat terjadi transformasi demokrasi. Beralihnya sistem pemerintahan dari demokrasi era orde baru ke demokrasi era reformasi dan sesudahnya, membuka ruang-ruang masalah baru dalam penyelenggaraan negara. Misalnya, ketika kekuasaan negara dibagi dalam bentuk otonomi daerah memunculkan permasalahan seperti konflik antar golongan dan etnik, korupsi, dan kuatnya keinginan memisahkan diri dari pusat (desintegrasi). Permasalahan penyelenggaraan negara yang muncul tersebut, diakibatkan oleh beberapa faktor seperti (Aziz, 2019):

(1) Ketidakseimbangan pembangunan, (2) Pengerukan sumber daya alam, (3) Kekerasan pada rakyat, (4) Kuatnya etnisitas pada masyarakat setempat (5) Jauh dari pusat pemerintahan, (6) Modernisasi yang keliru atau dipaksakan, (7) Distribusi ekonomi, posisi, atau jabatan yang tidak seimbang, (8) Persepsi yang keliru dari pemerintah pusat terhadap masyarakat lokal.

Salah satu masalah yang menonjol dan sangat mengganggu kehidupan bernegara adalah kasus korupsi pada setiap kelompok dan jenjang pemerintahan. Seperti disampaikan Komisi Pemberantasan Korupsi (KPK), bahwa sepanjang 2013 telah terjadi peningkatan jumlah perkara korupsi, (KPK, 2013). Dari 49 perkara yang ditangani pada 2012, tahun 2013 meningkat hampir dua kali lipat menjadi 70 perkara. Keseluruhan jumlah penanganan perkara tahun 2013 meliputi 76 kegiatan penyelidikan, 102 penyidikan, dan 66 kegiatan penuntutan, baik kasus baru maupun sisa penanganan pada tahun sebelumnya.

Demikian juga dengan operasi tangkap tangan (OTT) meningkat, yakni lebih dari 10 kasus OTT pada 2011. Jika diurut, kasus OTT pada 2010 satu kasus, 2009 dua kasus, dan 2008 empat kasus. Selanjutnya, Eksekusi yang dilakukan KPK terhadap putusan yang telah berkekuatan hukum tetap (inkracht) berjumlah 40, (KPK, 2013). Sementara itu, data terakhir tahun 2018 dari KPK, seperti yang diberitakan oleh Kompas.com bahwa, jumlah penyelidikan mengalami penurunan sebanyak 38,2 persen dari 123 kasus di 2017 menjadi 76 kasus di
2018. Kemudian angka penyidikan turun 29,8 persen dari 121 kasus menjadi 85 kasus, (Azanella, 2018). Namun demikian, volume jumlah kerugian negara meningkat.

Kasus korupsi hampir terjadi di semua wilayah (provinsi dan kabupaten) di Indonesia. Namun, hal yang unik di provinsi kecil wilayah timur Indonesia yaitu NTT kasus korupsi tinggi padahal memiliki pendapatan daerah yang sangat kecil dibandingkan provinsi lain, (Databoks, 2016). Provinsi NTT masuk lima besar Aparatur Sipil Negara (ASN) terkorup di Indonesia (Jehamat, 2018). ASN NTT berada di urutan keempat setelah ASN Provinsi Riau. Kemendagri pada 2018 merilis, jumlah ASN NTT yang berurusan dengan Tipikor sebanyak 183 orang. Di lain pihak NTT adalah provinsi yang memiliki tingkat kemiskinan 21,35 persen dari seluruh jumlah penduduk warga miskin di NTT mencapai 1,14 juta orang. Secara nasional, NTT menjadi provinsi ketiga termiskin di Indonesia (Hardum, 2019).

Kondisi korupsi yang demikian parah, merupakan konsumsi media massa untuk pemberitaan. Media massa memiliki peran yang besar dalam membangun persepsi carutmarutnya penyelenggaraan negara yang terjadi (Andrianti, 2015; Siregar, 2000). Penetrasi ketidakberesan penyelenggaraan masyarakat dan negara melalui lingkungan, media massa, serta teknologi media online cukup menghawatirkan. Hal ini bisa dilihat dari tingginya angka korupsi yang selalu disajikan oleh media massa dan diseminasi media online.

Bagi generasi muda, kondisi yang dihadapi dan pemberitaan saat ini menjadi stimulasi pembentukan persepsi negatif terhadap pengelolaan negara. Hal ini menjadi proses pembelajaran dan penanaman nilai-nilai secara langsung maupun tidak langsung dalam dirinya. Penyelewengan penyelenggaraan negara telah menjadi sumber "peneladanan" negatif tentang lingkungan di mana mereka berkembang. Seperti yang dikemukakan oleh Bajari (2017), tentang efek media dengan menyinggung Teori Kultivasi, bahwa:

Gerbner's opinion about Cultivation Theory that television is aforce that can dominantly influence modern society. The strength comes from the ability of television through various symbols to give such a diverse display of everyday life. Television is able to influence the audience, so that 
what is displayed on the screen is viewed as a real life.

Kondisi ini tentu memunculkan kecemasan jika memperhatikan posisi strategis anakanak remaja yang sedang mengalami masa internalisasi dan sosialisasi nilai-nilai kepribadian, pengembangan karakter, serta cinta tanah air di mana mereka hidup dan berkembang. Penayangan keburukan penyelenggaraan negara seperti korupsi melalui media dikhawatirkan akan menggagalkan upaya pembinaan melalui pembelajaran formal (sekolah). Apalagi, daya tarik media dengan pengalihan berbagai bentuk siaran yang bermuatan kekerasan dan dekonstruksi nilai-nilai moralitas, semakin kuat dan tidak memberikan peluang anak-anak untuk menghindarinya.

Hasil penelitian menunjukkan bahwa, media (massa) memiliki daya tarik yang kuat dibandingkan sumber atu media tradisional, (Mehraj, Bhat, \& Mehraj, 2014). Sehingga media memiliki kekuatan mempengaruhi. Namun demikian, jika media diarahkan untuk eduksi yang baik, media mampu menjadi sumber belajar dan inspirasi khalayak, tentang berbagai hal secara positif, (Flora, Maibach, \& Maccoby, 1989; Clark, 1983; Vivian, 2008; Morris \& Ogan Christine, 1996). Bahkan kehadiran internet sebagai media dengan jangkauan yang luas, telah memperpanjang jangkau bagi penduduk seperti petani untuk belajar lebih baik, (Destrian, Wahyudin, \& Mulyana, 2018). Selanjutnya, media bisa menjadi indikator pembeda antara masyarakat miskin tetapi maju dan tidak, dilihat dari kedekatan mereka dengan media, (Bajari, Susilawati, \& Setiaman, 2014).

Salah satu kunci pengembangan nilainilai toleransi adalah internalisasi secara dini. Di mana secara formal dilakukan dalam lingkungan pendidikan atau sekolah. Sekolah menjadi bagian yang terintegrasi dalam proses internalisasi anak didik serta menyiapkan mereka memahami keragaman dan perbedaan di antara mereka. Namun, untuk menjalankan fungsi sekolah seperti itu, lingkungan harus mengembangkan model komunikasi yang seimbang untuk membendung arus komunikasi sepihak dari media massa dan media lainnya. Lingkungan termasuk sekolah perlu mengembangkan media internal sekolah atau sebut saja media lokal yang digunakan di sekolah, yang mampu menyeimbangkan terpaan informasi.

Sebuah hasil penelitian menunjukkan bahwa media lokal yang dikelola lingkungan memiliki kekuatan dan membangun kemandirian. Friedman dan Wyatt yang meminjam konsep dalam riset media pembelajaran, (Friedman \& Wyatt, 2013), menjelaskan bahwa media lokal lebih mudah membangun kesadaran dan membangun pengetahuan bagi lingkungan. Penelitian lain menegaskan bahwa, media lokal yang dikembangkan secara partisipatif oleh kelompok mengisi kebutuhan pencarian informasi dan merekatkan hubungan antar individu dalam kelompok (Hornick, Ajzen, \& Albarracin, 2009).

Medialokalyangdikeloladandikembangkan sekolah, dapat mengajar secara baik, layaknya guru mengajar, bahkan kadang-kadang lebih baik dari apa yang dilakukan sebelumnya oleh para guru, (Schramm \& Chu, 2004). Kemudian, media yang dikembangkan oleh sekolah, walaupun tidak berpengaruh secara langsung, namun mampu memperkenalkan bahan untuk belajar. Media tersebut, menjadi alat yang mampu mengirimkan bahan instruksional dan sepertinya tidak berpengaruh secara langsung. (Gibbs, 2010; Graduated Student Instructor, 2016). Saran untuk mengembangkan kelas-kelas kecil dalam menanamkan nilai-nilai pada murid, menjadi sangat mahal jika harus diisi oleh guru, maka selanjutnya berpaling pada potensi media untuk meningkatkan produktivitas (Schramm \& Chu, 2004).

Sesuai perkembangan teknologi, website menjadi salah satu sumber belajar di samping media konvensional lainnya. Website memiliki kecepatan layanan informasi seiring dengan kemudahan mesin penyedia (google) pencarian informasi untuk pengguna, (Rikanita, 2017; Ta'meh, 2014; Kosasi, 2014). Saat ini, para pelajar, mahasiswa, pebisnis atau para pendidik telah banyak memanfaatkan mesin pencari untuk menemukan website atau blog yang menyediakan informasi yang dibutuhkan oleh mereka.

Sajian media menurut Schramm dan Chu (2004), media cetak seperti majalah internal dan mading (selanjutnya disebut mading), memiliki kedekatan dan kemampuan memberikan pengalaman yang lebih memadai. Sedangkan tingkat pengawasan sosial lebih banyak dimiliki oleh media masyarakat, (Hardt, 2008)

Dengan memperhatikan pada kuatnya 
peran media dan kedekatan remaja dengan media, seperti yang dijelaskan sebelumnya, maka perlu diupayakan sebuah tawaran reka bentuk diseminasi anti korupsi kepada remaja atau generasi muda melalui media alternatif yang lebih menarik. Dalam hal ini, melakukan upaya mencari stategi media internal terbaik untuk membangun persepsi dan kesadaran generasi muda dengan penggunaan media yang lebih dekat.

Berdasarkan latar belakang yang telah dipaparkan, penelitian ini berupaya untuk: (1) Mengukur tingkat pengaruh tunggal mading dan website terhadap sikap anti korupsi anak-anak, (2) Mengukur perbedaan pengaruh mading dan website dengan desain pesan informatif dan persuasif terhadap sikap anti korupsi anak-anak, (3) Menjelaskan pengaruh model kombinasi antara media dengan struktur pesan terhadap sikap anti korupsi anak-anak.

\section{METODE PENELITIAN}

Penelitian ini menggunakan dua tahap kajian lapangan. Tahap pertama yang sudah dilakukan adalah mengukur pengaruh media massa dan internet terhadap sikap anak-anak mengenai korupsi. Kajian awal menunjukkan bahwa media massa dan media sosial tidak memiliki pengaruh terhadap perubahan anti korupsi bagi anak-anak sekolah menengah. Dengan demikian, penggunaan media alternatif melalui eksperimen menjadi strategis dan bisa diandalkan untuk membangun sikap anti korupsi generasi muda (remaja) (Wahyudin \& Bajari, 2015).

Pada tahap dua ini dirancang sebuah penelitian eksperimen dengan empat kelompok percobaan. Penggunaan eksperimen didasarkan pada kekuatan untuk mengukur pengaruh secara signifikan dan peneliti berupaya merancang desain penelitian sesuai kebutuhan (Bajari, 2015). Di samping itu, eksperimen memberikan keleluasaan untuk mengeliminasi dan mengurangi pengaruh eksternal yang dianggap mengganggu (Rakhmat, 2017; Singarimbun \& Effendi, 1989).

Kelompok eksperimen yang dikembangkan dalam penelitian ini sebanyak empat kelompok. Masing-masing kelompok adalah dibedakan menurut kombinasi antara jenis media yang digunakan dengan jenis rancangan pesan yang dikembangkan. Jenis media yang digunakan dalam penelitian ini adalah; pertama, website yang diujicobakan secara online dengan penggunaansmartphoneparapeserta eksperimen dan laptop yang disiapkan oleh peneliti. Website ini dibuat secara khusus dan digunakan selama penelitian dilakukan. Kedua, mading sekolah yang dirancang untuk kebutuhan eksperimen dengan rancangan model vertikal dengan tiga kolom disertai elemen-elemen pokok mading.

Rancangan pesan yang dikembangkan adalah rancangan informatif dan persuasif. Rancangan informatif mengutamakan pada fakta tentang korupsi di Indonesia disertai dengan kerugian yang diterima oleh negara. Pesan ini lebih mengutamakan pesan satu sisi tentang fakta korupsi. Rancangan pesan persuasi mengutamakan imbauan anti korupsi dan imbauan tidak menjadi bagian dalam tindakan korupsi di masa yang akan datang. Pesan ini lebih mengutamakan sisi fakta dan pembentukan imbauan untuk membentuk sikap negatif terhadap tindakan korupsi.

Secara spesifik kelompok eksperimen ini adalah: pertama, kelompok mading dengan struktur pesan informatif. Kedua, kelompok mading dengan struktur pesan persuasif. Ketiga, kelompok website dengan struktur pesan informatif. Keempat, kelompok website dengan struktur pesan persuasif. Matrik kelompok percobaan dan pengukuran pengaruh perlakuan untuk melihat media yang paling efektif dalam membentuk sikap anti korupsi, digambarkan pada tabel 1 .

Hipotesis yang disusun untuk pengujian adalah: pertama, ada perbedaan pengaruh antara mading dengan pesan informatif dan pesan persuasif terhadap sikap anti korupsi para murid setelah percobaan. Kedua, ada perbedaan pengaruh antara website dengan pesan informatif dan pesan persuasif terhadap sikap anti korupsi para murid setelah percobaan. Ketiga, ada perbedaan pengaruh kombinasi media (mading dan website) dengan jenis pesan (informatif dan persuasif) terhadap sikap anti korupsi para murid setelah percobaan.

Rancangan penelitian yang digunakan adalah eksperimen dengan 4x3 rancangan percobaan (Rancop), artinya ada empat model intervensi terhadap empat kelompok percobaan untuk mengetahui model media percobaan yang memiliki rata-rata pengaruh paling kuat. Sedangkan dimensi yang diukur adalah tiga aspek sikap terhadap korupsi, yaitu aspek 
Tabel 1 Model Matrik Percobaan dan Pengukuran Hasil Penelitian

\begin{tabular}{clllll}
\hline & Media & \multicolumn{2}{c}{ Media Sekolah } & \multicolumn{2}{c}{ Website } \\
\cline { 3 - 6 } Sikap Anti & & Struktur & Struktur & Struktur & Struktur \\
Korupsi & Pesan A & Pesan B & Pesan A & Pesan B \\
\hline \multirow{2}{*}{ Sikap } & Kognitif & Rata-rata & Rata-rata & Rata-rata & Rata-rata \\
& Afektif & Rata-rata & Rata-rata & Rata-rata & Rata-rata \\
& Psikomotorik & Rata-rata & Rata-rata & Rata-rata & Rata-rata \\
\hline
\end{tabular}

Sumber: Dirancang oleh Peneliti, 2018

kognitif, afektif dan psikomotorik.

Aspek-aspek yang diukur dalam penelitian ini adalah: pertama, pengaruh ganda, yakni perbandingan dua rata-rata pengukuran sikap setelah para siswa mendapatkan percobaan media perlakuan dengan model struktur pesan yang berbeda dan model mading dan website secara terpisah, yang berisi informasi tentang korupsi. Skala pengukuran interval. Kedua, model pengaruh kombinasi yakni perbandingan dua rata-rata pengukuran sikap setelah para siswa mendapatkan percobaan media perlakuan dengan model struktur pesan yang berbeda dan model mading dan website secara bersamasama, yang berisi informasi tentang korupsi. Skala pengukuran interval. Ketiga, sikap anti korupsi yakni, kecenderungan negatif (ketidaksukaan dan kebencian, menjauhi atau menghindari) para siswa dari segi pengetahuan, perasaan/afeksi dan dorongan terhadap tindakan korupsi. Skala pengukuran interval.

Penelitian ini dilakukan di Kota Kupang wilayah timur Indonesia. Seperti diketahui Kota Kupang memiliki kasus korupsi (44 kasus masuk peradilan Tipikor) yang juga mendapatkan sorotan cukup luas dalam pemberitaan media, pada saat penelitian dilakukan. Alasan tingginya angka kejadian korupsi menjadi pilihan wilayah penelitian dengan asumsi bahwa para siswa akan diterpa informasi mengenai korupsi sehingga isu tersebut familier bagi mereka.

Penelitian menetapkan Sekolah Menengah Atas Negeri Satu Kota Kupang sebagai tempat eksperimen. Pada setiap kelompok percobaan diisi dengan 15 anak-anak yang dipilih melalui berbagai teknik pengelompokan peserta atau anggota eksperimen supaya kelompok homogen dan percobaan memberikan hasil yang maksimal. Teknik ini meliputi redemisasi atau pemilihan secara acak pada perlakuan pada setiap kelompok dan konstansi yakni menyeragamkan variabel yang melekat pada anak-anak yang dipilih sebagai peserta penelitian.

Setelah penelitian dilakukan dan pengukuran dilaksanakan, terdapat dua peserta yang hasil pengukurannya tidak dapat dianalisis karena pengisian lembar jawaban tidak lengkap. Satu kelompok penelitian hanya diisi oleh 13 anggota. Perbedaan jumlah kelompok ini, diperhatikan pengaruhnya terhadap hasil eksperimen dengan melihat perbedaan rata-rata kelompok terseut dengan kelompok lainnya.

Analisis data untuk mengukur pengaruh perlakuan menggunakan beberapa teknik pengujian yakni; uji beda dua rata-rata, anova (analysis of varians), dan uji t, serta uji perbandingan kelompok Kuskal-Wallis (H). Tingkat kepercayaan untuk masingmasing pengujian pada (p) 0,05. Sedangkan penyajian data menggunakan grafik dan tabel hasil uji pengaruh untuk menggambarkan hasil penelitian.

\section{HASIL DAN PEMBAHASAN}

Pada bagian awal hasil penelitian, dijelaskan terlebih dahulu terpaan media tentang berita korupsi terhadap para siswa yang menjadi objek penelitian. Pemberitaan media tentang kasus korupsi sangat gencar, terutama televisi dan surat kabar. Sedangkan radio lebih rendah karena mereka terikat pada format dan isi siaran. Selain berita tentang tangkap tangan dan penyidikan, liputan mengenai perilaku koruptor dalam sel tahanan dan keterlibatan dalam kancah politik, mendapatkan porsi luas dalam pemberitaan pada dua media tersebut. Oleh karena itu, perlu dibahas terlebih dahulu terpaan media tersebut terhadap siswa yang diteliti untuk mengukur kekuatan pengaruh eksternal media massa. 
Gencarnya ekspos media massa mengenai kasus korupsi, diperkirakan akan mempengaruhi hasil eksperimen dalam uji coba media yang dikembangkan. Terpaan media mengenai isu atau berita korupsi dapat dilihat dari normalitas sebaran pada pengolahan data awal. Secara statistik Sebaran skor mendekati garis linier pada plot kurva tersebut dengan skor terendah teretak pada angka 11 dan tertinggi 41. Dengan demikian keragaman skor cenderung berkumpul pada garis linier dan hanya dua data observasi yang menjauh dari garis linier, dengan demikian data yang dikumpulkan dikatakan normal. Sedangkan untuk pergerakan skor terpaan media tentang korupsi bergerombol pada rentang kurang dari sebelas dan kurang dari dua puluh satu. Artinya media digunakan oleh para siswa atau responden dalam jumlah yang kecil atau jarang digunakan. Hal ini menunjukkan bahwa media massa tidak menjadi prioritas kebutuhan mereka dalam mencari informasi.

Secara deskriptif, hasil pengolahan data lanjutan menunjukkan bahwa, anak-anak memiliki tingkat terpaan televisi tentang berita korupsi sebagai berikut; terpaan rendah sekali berkisar 10 siswa atau $17,2 \%$, rendah sebanyak 23 atau 39,7\%, moderat berkisar 17 siswa atau 29,3\%, tinggi sekitar 7 siswa atau $12,1 \%$, serta sangat tinggi sebanyak satu orang siswa atau 1,7\%. Dari data deskriptif tersebut dapat disimpulkan, bahwa sebagian besar siswa yang terlibat dalam eksperimen ini termasuk dalam kategori rendah terpaan televisinya. Artinya mereka jarang menyaksikan atau menonton berita tentang korupsi atau mendapatkan informasi melalui televisi. Bahkan hanya satu orang siswa saja yang memiliki kategori sangat tinggi untuk terpaan berita informasi melalui televisi.

Jika memperhatikan pada analisis deskriptif terpaan televisi yang rendah terhadap siswa, maka hasilnya tidak jauh berbeda dengan analisis surat kabar. Surat kabar bukan media yang favorit untuk anak-anak. Data deskriptif menunjukkan bahwa; tingkat terpaan surat kabar mengenai berita korupsi terhadap anakanak mayoritas sangat rendah, yakni sebanyak 26 anak atau 44,8\%. Kemudian pada kategori rendah sebanyak 23 anak (39,7\%), kategori sedang sebanyak delapan anak atau 13,8\%, kategori tinggi hanya satu anak $(1,7 \%)$, serta tidak ada anak yang masuk ke dalam kategori sangat tinggi. Kesimpulan dari analisis deskripsi tersebut yaitu, surat kabar tidak menjadi rujukan anak-anak untuk mencari informasi termasuk berita korupsi.

Penggunaan radio juga tidak menunjukkan data yang cukup baik untuk menjadi sumber informasi mengenai peristiwa korupsi bagi anak-anak. Sebagian besar dari mereka yakni 21 orang $(36,2 \%)$ menyebutkan bahwa dirinya tidak pernah dan sangat jarang mendapatkan informasi tersebut, kemudian sebagian besar dari mereka menyebutkan jarang mendapatkan informasi tersebut (27 anak atau 46,6\%), serta lima siswa $(8,6 \%)$ menyebutkan sedang-sedang saja atau moderat, dan lima orang $(8,6 \%)$ menyebutkan cukup tinggi mendapatkan informasi tentang kejadian korupsi melalui radio.

Berdasarkan analisis pada tiga sumber informasi media massa, tampak bahwa media massa tidak mendapatkan tempat yang baik di kalangan generasi muda atau anak-anak SMA yang menjadi objek penelitian. Sebagian besar hasil penelitian menunjukkan bahwa anak-anak tidak menjadikan media massa sebagai sumber rujukan informasi untuk mendapatkan berita korupsi. Hal ini semakin menguatkan bahwa pentingnya memanfaatkan media alternatif untuk membantu generasi muda memahami kasus korupsi sebagai bagian dari keburukan penyelenggaraan negara.

Temuan hasil penelitian selanjutnya adalah deskripsi tentang normalitas pengukuran penggunaan media online termasuk media sosial oleh para siswa. Hasil pengolahan menunjukkan bahwa, skor cenderung mendekati keseragaman pada masing-masing kelompok. Namun demikian masih bisa dikatakan normal, ketika mendekati garis linier. Selanjutnya skor observasi pada histogram menunjukkan bahwa penggunaan media online sebagian besar terletak pada interval moderat diikuti, rendah dan tinggi. Dengan demikian aktivitas penggunaan media online untuk mendapatkan informasi berita atau informasi tentang korupsi oleh para siswa cukup baik jika dibandingkan dengan penggunaan media massa.

Analisis deskriptif penggunaan media online oleh anak-anak menunjukkan, bahwa tren penggunaan media online bergerak dari skor rendah, kemudian mayoritas responden sedang, serta terdapat sebagian dari mereka memilih kategori tinggi dalam memanfaatkan media online untuk mencari berita korupsi. Data 
tren ini, setidaknya menunjukkan skor yang lebih baik jika dibandingkan dengan media mainstream atau media massa. Hasil penelitian ini, memberikan peluang untuk mendorong penggunaan media online sebagai media alternatif penyediaan informasi yang membantu pembentukan sikap peduli kasus korupsi dan atau penindakan terhadap pelaku korupsi.

Sekolah yang dijadikan tempat eksperimen sudah memiliki mading yang dikelola oleh para murid. Penggunaan mading merupakan sesuatu yang populer di kalangan para murid di Kupang. Hasil penelitian penggunaan mading menunjukkan penyebaran pada kelompok tertentu.

Hasil pengukuran interaksi anak dengan mading, cenderung memiliki rentang lebar dari garis linier dan tidak secara tegas menunjukkan kenormalan data. Jika skor pengukuran tersebut dikelompokkan, maka didapat hasil sebagai berikut; pertama, skor penggunaan mading sekolah bergerak dari nilai rendah, moderat dan tinggi. Kedua, sebagian skor berkelompok pada interval sedang/moderat $(62,1 \%)$ dan rendah (27,6\%). Dengan demikian penggunaan mading tidak terlalu menggembirakan di kalangan para siswa. Sebagian besar dari mereka hanya mengenal dan mengetahui keberadaan mading sekolah.

Hasil pengukuran terhadap media massa, media online dan mading, selanjutnya dielaborasi menggunakan uji korelasi dengan variabel sikap eksisting atau sebelum riset eksperimen dilakukan (pre-test). Hasil analisis korelasi menunjukkan bahwa sebagian besar media yang dianalisis tidak memiliki hubungan yang signifikan dengan variabel-variabel yang diukur ketika eksperimen dilakukan. Media massa (TV, radio dan surat kabar), media online yang digunakan dan mading sekolah, tidak memiliki hubungan yang signifikan secara tunggal. Artinya, media tersebut dianggap tidak mengganggu variabel-variabel sikap anti korupsi yang terbentuk pada siswa, sehingga pengukuran pasca eksperimen dianggap hasil yang tunggal.

Setelah deskripsi hasil penelitian atau telaahan terhadap variabel media massa, internet (media online dan media sosial), dan mading yang sudah ada di sekolah, selanjutnya dipaparkan hasil eksperimen mading dan website yang dikembangkan secara khusus untuk penelitian yang dikombinasikan dengan pesan informatif dan persuasif.

Eksperimen ini mencoba menguji hipotesis sebagai berikut: 1) Ada perbedaan pengaruh antara mading dengan pesan informatif dan pesan persuasif terhadap sikap anti korupsi para murid setelah percobaan; 2) Ada perbedaan pengaruh antara website dengan pesan informatif dan pesan persuasif terhadap sikap anti korupsi para murid setelah percobaan; 3) Ada perbedaan pengaruh kombinasi media (mading dan website) dengan jenis pesan (informatif dan persuasif) terhadap sikap anti korupsi para murid setelah percobaan.

Empat model eksperimen telah diuji coba terhadap 58 anak-anak SMA Negeri Kota Kupang untuk menguji hipotesis yang dikembangkan. Masing-masing model mading dengan pesan informatif dan pesan persuasif dipajang pada dinding pengumuman sekolah untuk dibaca selama 30 menit masa percobaan oleh anak-anak yang terlibat dalam eksperimen. Di lain pihak website sekolah berbasis desktop dan android dibuka pada masing-masing gadget dan laptop anak-anak. Mereka diberikan instruksi untuk membaca dan menyimak isi pesan anti korupsi pada media tersebut. Desain dan kelompok yang dikembangkan adalah; mading dengan pesan informatif, mading dengan pesan persuasif, website dengan pesan informatif dan website berisi pesan persuasif. Isi pesan menyajikan tentang pembentukan sikap anti korupsi.

Data hasil pengukuran sebelum percobaan dan setelah percobaan dibandingkan rata-rata atau mean-nya satu sama lain. Hasilnya dapat dilihat pada uraian deskriptif yang menunjukkan efektivitas dari masing-masing desain percobaan atau eksperimen. Hasil percobaan terhadap 58 siswa yang terbagi dalam empat kelompok eksperimen, ditunjukkan pada gambar 1, 2, 3, dan 4.

Pembahasan pertama menguraikan hasil pengukuran (pre-test dan post-test) dari efektivitas mading dengan pesan informatif, mading dengan desain pesan persuasif, website dengan desain pesan informatif dan website dengan desain pesan persuasif.

Gambar 1 menjelaskan perbandingan dua rata-rata dari hasil pengukuran sebelum dan sesudah. Gambar tersebut menunjukkan bahwa, terdapat perbedaan rata-rata pre-test dan posttest untuk dimensi sikap kognitif, dimensi sikap afektif dan dimensi sikap psikomotorik terhadap 


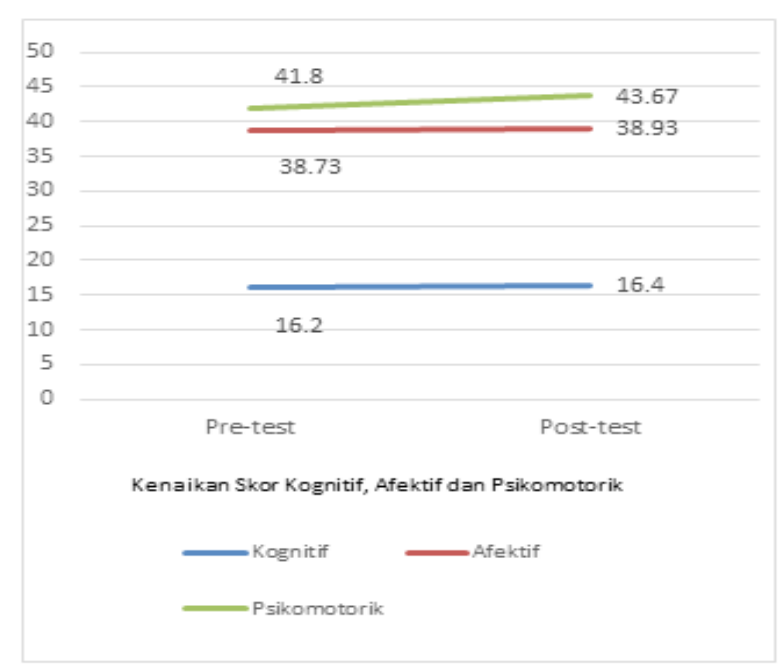

Sumber: Hasil pengolahan data penelitian, 2018

Gambar 1 Perbandingan Skor Rata-rata Sikap Anti Korupsi Akibat Pengaruh Mading-Pesan Informatif

sikap anti korupsi siswa setelah diberikan perlakuan dengan mading dengan rancangan pesan informatif. Pesan informatif mading meningkatkan rata-rata sikap anti korupsi anakanak. Pada dimensi sikap kognitif meningkat dari skor rata-rata 16,20 menjadi 16,40 , pada dimensi afektif dari 38,73 menjadi 38,93 dan pada psikomotorik dari 41,80 menjadi 43,67.

Melalui pengujian terhadap hipotesis penelitian, terbukti bahwa terjadi peningkatan secara signifikan akibat atau pengaruh perlakukan mading dengan rancangan pesan informatif terhadap sikap positif anti korupsi, namun hanya signifikan pada dimensi sikap psikomotorik. Kesimpulannya adalah, mading dengan rancangan pesan informatif, mempengaruhi peningkatan skor rata-rata sikap psikomotorik anti korupsi anak-anak, dengan hasil pengujian $\mathrm{t}$ statistik $=2,256$ dan signifikan pada $\mathrm{p}$ value $=0,0406$ (one-tailed), tetapi tidak signifikan pada dimensi sikap kognitif dan afektif.

Gambar 2 menjelaskan dua rata-rata hasil pengukuran sebelum dan sesudah. Gambar tersebut menunjukkan bahwa, terdapat perbedaan rata-rata pre-test dan post-test untuk dimensi sikap kognitif, dimensi sikap afektif dan dimensi sikap psikomotorik terhadap korupsi dari para siswa setelah diberikan perlakuan dengan majalah dinding dengan rancangan pesan persuasif. Pesan persuasif mading meningkatkan rata-rata sikap anti korupsi anakanak. Pada dimensi sikap kognitif meningkat

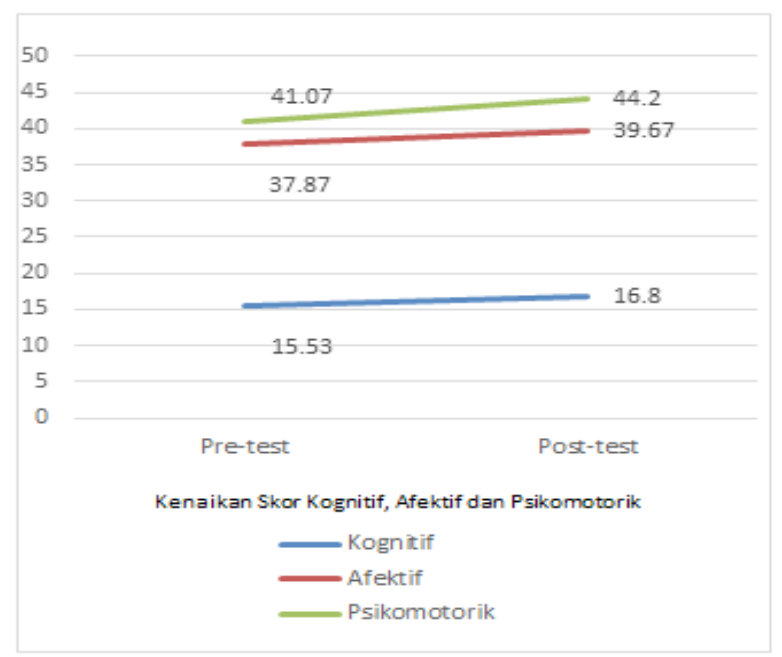

Sumber: Hasil pengolahan data penelitian, 2018

Gambar 2 Skor Rata-rata Sikap Akibat Anti Korupsi Akibat Pengaruh Mading-Pesan Persuasif

dari skor rata-rata 15,53 menjadi 16,80 , pada dimensi afektif dari 37,87 menjadi 39,67 dan pada psikomotorik dari 41,07 menjadi 44,20.

Setelah dilakukan pengujian terhadap hipotesis penelitian, bahwa telah terjadi peningkatan secara signifikan akibat perlakukan mading dengan rancangan pesan persuasif terhadap sikap positif anti korupsi. Hasil uji menunjukkan perbedaan rata-rata signifikan pada dimensi sikap kognitif, afektif dan psikomotorik. Kesimpulannya adalah, mading dengan pesan persuasif mempengaruhi peningkatan skor rata-rata sikap kognitif, afektif dan psikomotorik sikap anti korupsi anak-anak. Hasil pengujian $t$ statistik, pada sikap kognitif, $\mathrm{t}=3,676$ dan signifikan pada $p$ value $=0,0025$ (one-tailed). Hasil pengujian t statistik, pada sikap afektif $\mathrm{t}=2,483$, signifikan pada $p$ value $=$ 0,026 (one-tailed). Kemudian, Hasil pengujian t statistik, pada sikap psikomotorik $\mathrm{t}=2,775$ dan signifikan pada $p$ value $=0,014$ (one-tailed).

Pembahasan kedua adalah pengukuran model website dengan rancangan pesan informatif dan persuasif. Gambar 3 menyajikan hasil intervensi website dengan pesan informatif. Tampak bahwa hasil dua pengukuran percobaan tidak terdapat peningkatan yang nyata. Demikian juga dengan hasil pengujian statistik, bahwa tidak terdapat pengaruh yang signifikan dari media website dengan pesan persuasif terhadap perubahan sikap anti korupsi anak-anak.

Model uji coba berikutnya adalah website 


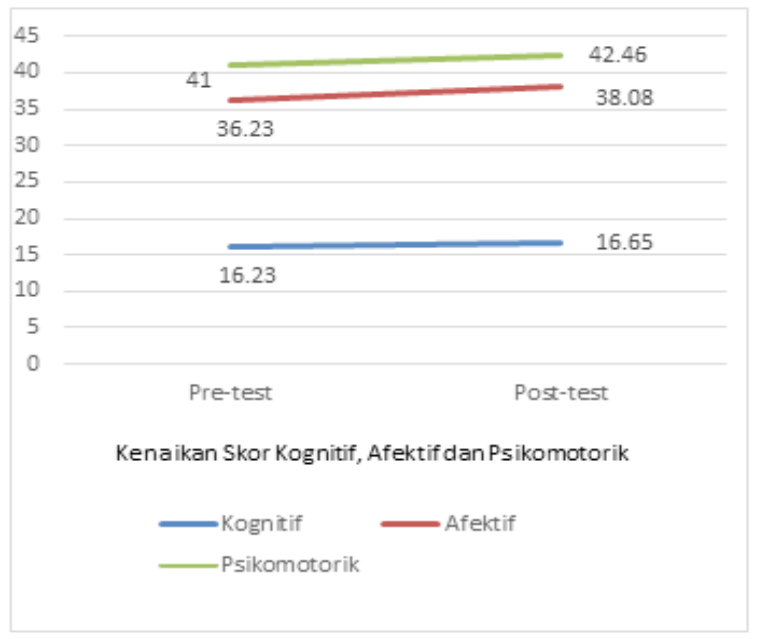

Sumber: Hasil pengolahan data penelitian, 2018

\section{Gambar 3 Perbandingan Skor Rata-rata Sikap Anti Korupsi Akibat Pengaruh Website-Pesan Informatif}

dengan rancangan pesan persuasif. Gambar 4 menyajikan hasil intervensi website dengan model persuasif. Pada website dengan model persuasif, tampak bahwa hasil dua pengukuran percobaan tidak terdapat peningkatan yang nyata. Bahkan pada satu dimensi, terjadi penurunan skor rata-rata sesudah percobaan (dimensi psikomotorik). Demikian juga dengan hasil pengujian statistik, bahwa tidak terdapat pengaruh yang signifikan dari media website dengan pesan persuasif terhadap perubahan sikap anti korupsi anak-anak.

Selanjutnya pembahasan ketiga, memaparkan hasil pengujian yang mengukur perbedaan rata-rata dari empat kelompok media perlakuan dengan masing-masing rancangan pesan. Pada tabel 3, perbandingan rata-rata diketahui bahwa terdapat perbedaan antara keempat kelompok jika diukur setelah eksperimen dilakukan. Mading dengan rancangan pesan persuasif memiliki skor rata-rata pengaruh paling tinggi, kemudian diikuti oleh mading dengan rancangan pesan informatif, website dengan rancangan pesan persuasif dan website dengan rancangan pesan informatif.

Hasil pengujian empat kelompok sekaligus dengan menggunakan tes Kruskal Wallis Test menunjukkan bahwa perbedaan rata-rata keempat kelompok tersebut adalah signifikan dengan koefisien $\mathrm{H}$ hitung $=11,60$ dan signifikansi atau $p$-value 0,0086 . Dengan demikian dapat diartikan bahwa mading dengan

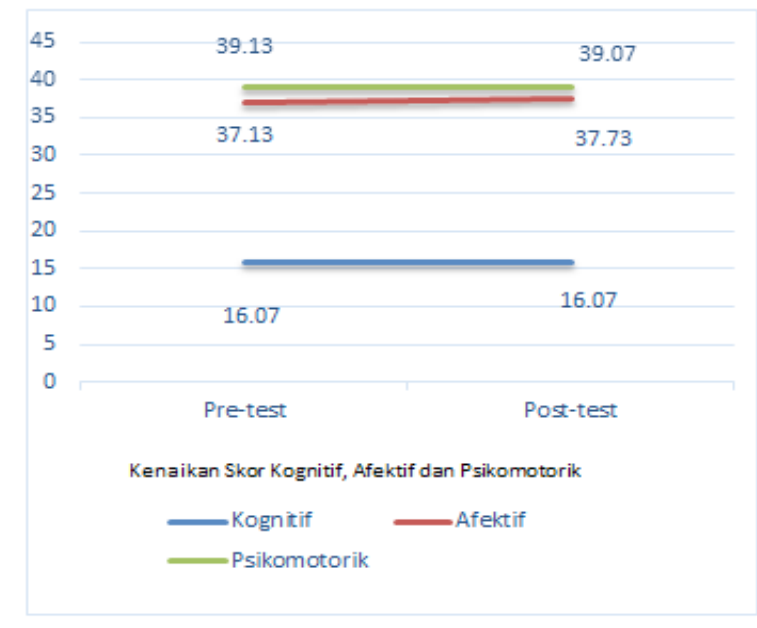

Sumber: Hasil pengolahan data penelitian, 2108

\section{Gambar 4 Perbandingan Skor Rata-rata Sikap Anti Korupsi Akibat Pengaruh Website-Pesan Persuasif}

pesan persuasif secara signifikan memberikan peningkatan skor rata-rata sikap anti korupsi lebih tinggi dibanding tiga desain media lainnya.

Hasil penelitian yang disajikan telah menunjukkan perbedaan pengaruh di antara keduamediayang dieksperimenkan. Hakikatnya, membandingkan dua media memiliki resiko

\section{Tabel 3 Perbandingan Rata-rata Media Perlakuan dan Uji Statistik Perbandingan Rata-rata Skor Media Perlakuan (Kruskal-Wallis Test)}

\begin{tabular}{cccc}
\hline $\begin{array}{c}\text { Mading } \\
\text { Informatif }\end{array}$ & $\begin{array}{c}\text { Mading } \\
\text { Persuasif }\end{array}$ & $\begin{array}{c}\text { Website } \\
\text { Informatif }\end{array}$ & $\begin{array}{c}\text { Website } \\
\text { Persuasif }\end{array}$ \\
\hline Mean $)$ & (Mean) & (Mean $)$ & $($ Mean $)$ \\
\hline Median & $\mathrm{n}$ & $\begin{array}{c}\text { Avg. } \\
\text { Rank }\end{array}$ & \\
\hline 100.00 & 15 & 34.17 & Group 1 \\
101.00 & 15 & 38.37 & Group 2 \\
96.00 & 13 & 25.92 & Group 3 \\
92.00 & 15 & 19.07 & Group 4 \\
98.50 & 58 & & Total \\
\hline
\end{tabular}

$\mathrm{H}$

11.660 (corrected for ties)

3 d.f.

$.0086 \quad \mathrm{p}$-value

Sumber: Hasil pengolahan data penelitian, 2018. 
tersendiri, apalagi jika menggunakan desain eksperimen sebagai metode pengukuran. Hal ini, mengingat beberapa faktor yang perlu diperhitungkan dalam melihat kekuatan dan kelemahan dari masing-masing media. Setiap media pasti memiliki karakteristik yang berbeda, yang akan mempengaruhi media tersebut dalam menjalankan fungsinya pada pengguna. Oleh karena itu, ketika akan mengukur penerimaan isi pesan yang sama dan disajikan dengan cara yang sama memiliki tingkat kesulitan tersendiri. Media berbeda akan memberikan pengaruh berbeda walaupun isi dan cara penyajian pesan sama.

Demikian halnya dengan isi pesan sikap anti korupsi yang disajikan dengan cara informatif dan persuasif melalui website dan mading akan mendapatkan respons penerimaan yang berbeda karena hakikat dari dua media tersebut juga berbeda. Mading memiliki kekuatan dalam ruang baca atau space yang lebih besar, daya tarik, dan penyimpanan lebih lama. Sementara itu, website memiliki kecepatan up-date dan kedekatan dengan pembaca karena dapat dibuka di mana saja melalui gadget atau desktop.

Kehadiran website, blog dan bentuk tulisan lain dalam ruang virtual sebagai media komunikasi, membutuhkan pendekatan riset tersendiri. Puschman (2015), menyebutkan bahwa riset terhadap media seperti blog dan website membutuhkan pendekatan tersendiri. Demikian hanya dengan kemampuan mading sebagai media komunikasi, ruang ekspresi yang menjadi kebanggaan sebuah sekolah adalah tempat berkomunikasi para murid ketika memperkenalkan karya dan pikiran mereka. Menurut Santoso, (2007), mading merupakan salah satu wujud keterampilan menulis. Kemudian, Santoso (2007), menyebutkan pula bahwa mading sangat mungkin diselenggarakan karena merupakan salah satu bentuk majalah sekolah yang sederhana dengan biaya yang murah sehingga lebih mungkin dilaksanakan di mana saja.

Media memiliki kemampuan memengaruhi dan membentuk sikap pembaca, apapun bentuknya. Seperti disebutkan oleh Bajari (2017), media memiliki pengaruh terhadap anak-anak remaja. Dengan menggunakan Teori Prososial Kognitif, hasil penelitian itu menunjukkan bahwa, "use of the internet or the website presenting news or information about conflict, violence, and criminality correlated positively and significantly with the students or the Indonesian Children's Patriotism." Serta, "the message contents of television and internet are positively and significantly correlated with students or the Indonesian children's patriotism." Secara keseluruhan media menunjukkan efek yang berbeda, bahwa penetrasi media mengenai konflik, korupsi, dan kejahatan kriminal mendorong kekhawatiran dan kecintaan pada tanah air sebagai bangsa, (Bobok, 2016). Anak-anak memiliki rasa simpati dan cinta tanah air yang baik manakala melihat peristiwa yang memprihatinkan tersebut. Hampir seluruh terpaan media (massa dan internet) secara simultan memiliki pengaruh terhadap rasa cinta tanah air.

Penelitian klasik dari Schramm (1984), dalam riset "Pengaruh Media Besar dan Media Kecil, Alat dan Teknologi untuk Pengajaran," telah menunjukkan hasil yang sama bahwa media instruksional yang dikembangkan dengan baik memberikan dampak pada hasil belajar. Media digital (komputer) menunjukkan hasil nilai post-test standar yang signifikan lebih baik dicapai oleh kelompok eksperimen dalam proses pembelajaran. Di samping itu, hasil penelitian yang lain menyebutkan bahwa siswa keperawatan yang belajar tentang merawat ibu yang baru melahirkan dan farmakologi dengan menggunakan komputer (CAI) telah menghemat waktu yang signifikan dalam menyelesaikan bahan pelajaran, (Oberty, 1992a new signal transduction inhibitor drug of chronic myeloid leukemia; Sudaryanto \& Surakarta, 2008; Fandianta, Sanjaya, 2013; Ahadzadeh \& Sharif, 2017)Demikian halnya dengan media lain yang dikembangkan oleh sekolah atau lembaga pendidikan menunjukkan hasil-hasil yang signifikan dalam membentuk pengetahuan. Schramm (1984) dan Sumintono, dkk., (2012) menyebutkan bahwa mahasiswa yang belajar dengan berbagai media (multimedia) menunjukkan hasil belajar signifikan yang lebih baik dari hasil kelompok lainnya. Namun demikian, dalam eksperimen Spencer yang dikutif oleh Schramm, dijelaskan, bahwa tidak ada perbedaan hasil yang signifikan tentang penggunaan TV instruksional dengan mesin belajar.

Berdasarkan pada hasil-hasil penelitian terdahulu tersebut, penelitian ini memberikan hasil yang mempertegas bahwa media lokal seperti mading sekolah, juga memiliki 
kemampuan dalam membentuk sikap siswa terhadap tindakan korupsi.

Keanekaragaman jenis dan kemampuan media komunikasi, yang menjadi pokok perhatian utama dalam pemanfaatan media untuk komunikasi yang bertujuan untuk melakukan perubahan, adalah sejauh mana media yang bersangkutan mendukung tujuan komunikasi. Secara umum, media komunikasi membantu dalam menambah minat, variasi, dampak, serta pesan yang disajikan cenderung lebih lama tinggal dalam memori khalayak. Misalnya dikemukakan oleh Curtis, dkk. (Curtis, 1996) dan Bajari (Bajari, 2013), bahwa, media visual meningkatkan pemahaman sampai $200 \%$ dalam pengajaran, meningkatkan daya ingat sekitar 14-38\%, dan efisiensi waktu yang diperlukan sampai $40 \%$ untuk menjelaskan konsep tunggal dalam presentasi bisnis. Beberapa hasil penelitian tentang kemampuan media kecil atau media dengan sirkulasi terbatas yang dikumpulkan oleh Schramm (1984), memberikan bukti-bukti bahwa; Pertama, kombinasi media audio visual memberikan hasil yang jauh lebih besar dalam mempengaruhi khalayak. Kedua, Penggunaan gambar hidup memberikan hasil 26\% lebih tinggi dalam tes mengenai materi yang disajikan, dibandingkan dengan khalayak yang belajar hanya lewat peta, model, gambar, dan karyawisata. Ketiga, presentasi dengan menggunakan kombinasi pengajaran berprogram, film bicara, tape slide, dan tape latihan (multimedia), memberikan hasil belajar yang signifikan dari pada belajar lewat bantuan seorang guru.

Hasil penelitian yang dilakukan telah menunjukkan bahwa secara keseluruhan mading memiliki kekuatan dalam membentuk sikap anti korupsi, terutama, jika mading tersebut dikombinasikan dengan rancangan pesan persuasif. Hasil uji coba dan uji statistik menunjukkan bahwa, kombinasi keduanya memberikan hasil yang maksimal dalam mempengaruhi siswa untuk membenci tindakan korupsi. Karakteristik mading sebagai media yang murah, ekspresif, tersimpan lebih lama dengan ruang baca yang luas, serta tradisi yang kuat dalam lingkungan pendidikan menengah, merupakan modal kekuatan dari mading. Mading atau mading memiliki kemampuan mengembangkan sikap kognitif, afektif, psikomotorik siswa, (Zubaidah \& Saptono, 2004). Selanjutnya mereka juga mengaskan bahwa mading merupakan media komunikasi dan informasi yang mudah dan murah. Terlebih pada sekolah yang menekankan prinsip kesederhanaan pada biaya, dapat memenuhi tuntutan kesederhanaan itu, bahkan lebih mampu memberi manfaat pada pengembangan setiap mata pelajaran yang lebih dari itu. Demikian halnya dengan temuan di New Jersey bahwa, para guru menyadari nilai mading sebagai alat bantu pengajaran di bidang materi pelajaran dan pembelajaran sosial; dan bahwa, seperti dalam semua alat pengajaran yang baik, (Parker, 2014). Penggunaan mading merupakan sarana untuk mencapai tujuan pembelajaran dan ketika guru dan siswa merencanakan dan mengevaluasi bersama-sama pembelajaran, hasil yang lebih besar terjadi.

Namun demikian, dalam setting pembelajaran yang berhasil tidak sematamata oleh alat bantu atau media. Pembelajaran melibatkan berbagai saluran media. Para guru tentu memiliki kemampuan dalam merancang dan mengombinasikan saluran-saluran komunikasi pembelajaran. Setiap guru atau pengajar memiliki pertimbangan ini cukup menentukan untuk beberapa alasan. Menurut Adams (1982), pertama, setiap media atau saluran memiliki karakteristik masing-masing, di mana karakteristik tersebut menjadi kelebihan dan kekurangan masing-masing media. Kedua, setiap kegiatan komunikasi memiliki tujuan akhir yang berbeda, maka dengan kemampuan memilih media, tujuan tersebut dapat dicapai lebih cepat dan efisien. Selanjutnya, buktibukti penelitian lain, menyatakan bahwa ketika seorang perencanakomunikasimengembangkan penggunaan media dengan kombinasi yang baik dengan penyampaian pesan secara verbal, akan memberikan hasil yang lebih kuat dan efektif dalam berbagai kebutuhan komunikasi, daripada tanpa media sama sekali. Faktor-faktor yang mendukung keberhasilan komunikasi bermedia dengan pendekatan multimedia menurut Kemp (1963), yaitu; cenderung meningkatkan pengertian atau pemahaman terhadap suatu topik pembicaraan, meningkatkan daya tarik bagi khalayak, mengajarkan keahlian lebih efektif bagi para pengguna, mendorong atau merangsang khalayak pengguna untuk bertindak jika memang dibutuhkan tindakan, menumbuhkan sikap yang diinginkan terhadap materi yang dibicarakan, serta memperpanjang waktu penyimpanan informasi atau biasa 
dikenal dengan terdokumentasikan.

Mading memiliki peran membangun terpaan selektif (selective exposure). Khalayak cenderung memperhatikan pesan-pesan komunikasi yang selaras dengan kebutuhan, sikap, dan kepercayaannya sehingga pesanpesan yang tak berkaitan dengan dirinya akan dilewatkan begitu saja. Di samping itu, kekuatan mading dalam riset yang digabungkan dengan rancangan persuasi, memberikan hasil yang maksimal. Persuasi adalah gaya penyajian pesan yang dikelola sedemikian rupa. Bagaimanapun pesan yang dikelola dengan baik akan memberikan dampak yang baik. Pesan adalah sangat krusial dalam penyampaian komunikasi. Seperti dikatakan Azjen (2014), "Potential confounding of a more serious kind can occur in the case of message factors because variations message features are often accompanied by differences in content. Message factors concern the ways in which information is communicated to the audience."

Persuasi merupakan gaya penyajian pesan yang lebih mengena, menyentuh motif, mendorong atau menggerakkan perilaku komunikate, (Rakhmat, 2018 dan Husband \& Hellier, 2011). Selanjutnya, Taillard (2000), menyebutkan bahwa, "Two of the goals of human communication are: to be understood and to be believed. In persuasive communication, both of these acts are fulfilled." Namun demikian, persuasi akan berhasil jika kondisi sebelumnya memungkinkan untuk berubah. Manusia cenderung berubah karena ada niat sebelumnya. Dalam hal inilah persuasi lebih berhasil, karena, niat perilaku dan kontrol perilaku yang dirasakan adalah prediktor perilaku. Ketika manusia termotivasi untuk mengubah perilaku, maka semakin kuat niat untuk mengubah perilaku, dan semakin besar kemungkinan perilaku tersebut akan dijalankan (Teng, Khong, \& Goh, 2015).

\section{SIMPULAN}

Hasil penelitian ini memberikan beberapa kesimpulan sebagai berikut; pengaruh mading berbeda secara signifikan dengan website dalam mempengaruhi sikap anti korupsi para murid setelah percobaan. Mading dengan pesan persuasif memiliki kemampuan untuk membentuk sikap anti korupsi pada wilayah penelitian yang memiliki angka kasus korupsi tinggi. Bahkan mading dengan pesan informatif mampu membentuk pesan antikorupsi pada dimensi psikomotorik, walaupun pada dimensi lainnya tidak.

Website tidak memiliki pengaruh yang signifikan terhadap pembentukan sikap anti korupsi para murid. Hal ini ditemukan pada semua desain website baik dengan pesan informatif maupun dengan pesan persuasif.

Kombinasi mading dengan pesan persuasif memberikan skor rata-rata sikap anti korupsi lebih tinggi secara signifikan dibandingkan dengan desain atau kelompok eksperimen lainnya. Mading dengan pesan persuasif lebih unggul jika dibandingkan dengan mading dengan pesan informatif, website dengan pesan persuasif dan website dengan pesan informatif setelah percobaan dilakukan. Kombinasi tersebut memberikan hasil maksimal terhadap pembentukan sikap anti korupsi.

Beberapa saran yang patut dikembangkan ke depan, dalam upaya pencegahan korupsi sejak dini melalui sosialisasi bagi generasi muda, adalah; melakukan upaya pengembangan model mading dan struktur pesan persuasif sangat dianjurkan pada proses pengembangan model atau material sosialisasi anti korupsi bagi generasi muda. Desain ini efektif dalam memberikan pemahaman tentang bahaya korupsi pada anak-anak.

Uji coba media pada jenis isu dan wilayah yang berbeda, perlu dilakukan untuk memperkuat metodologi serta menyempurnakan hasil penelitian. Hal ini sangat penting dalam memahami sebuah perubahan sikap dan perilaku akibat sebuah intervensi media dengan memperhatikan pengaruh berbagai aspek untuk kemudian dijadikan sebagai variabel yang dilibatkan dalam proses eksperimen (uji coba), sehingga analisis semakin tajam.

Perlu pengembangan instrumen pengukuran baku dalam menilai perubahan sikap anti korupsi dengan melihat pada hasil penelitian yang dilakukan, mengingat tiga jenis desain lainnya pada penelitian ini tidak berpengaruh secara signifikan. Bagaimanapun, secara hipotesis, setiap desain memiliki kelebihan dan kekurangan. Oleh karena itu, penelitian selanjutnya perlu menguji lebih jauh kecocokan antara desain media dan pesan dengan jenis sasaran atau kelompok khalayak, demi membantu sosialisasi anti korupsi bagi masyarakat. 


\section{DAFTAR PUSTAKA}

Adams, J. R. (1982). Media planning (Second Edi). London: Bussines Books.

Ahadzadeh, A. S., \& Sharif, S. P. (2017). Online health information seeking among Malaysian women: Technology acceptance model perspective. SEARCH Journal, 9(1), 47-70.

Ajzen, I. (2014). Persuasive communication theory in social psychology: a historical perspective. Amherst.

Andrianti, N. (2015). Peran media massa nasional dalam politik internasional. Informasi, 45(1).

Azanella, L. A. (2018). Data KPK, angka penindakan korupsi pada 2018 turun 41,2 persen. Diakses dari: https://nasional. kompas.com/read/2018/12/10/15314821/ data-kpk-angka-penindakan-korupsi-pada2018-turun-412-persen.

Aziz, A (2019). Transformasi konflik dan peran pemerintah daerah. Journal of Urban Sociology, 2(1), 28-41.

Bajari, A. (2013). Perencanaan media. In K. Mada \& A. Bajari (Eds.), Perencanaan Komunikasi. Bandung: Ultimus.

Bajari, A. (2015). Metode penelitian komunikasi; Prosedur, tren dan etika (2nd ed.). Bandung: Simbiosa Rekatama.

Bajari, A. (2017). Three C's on Television and Internet. The Influence of Conflicts, Corruptions and Crimes Reporting Towards Sense of Patriotism of Indonesian Children. In Journalism and Mass Communication (Vol. 91, pp. 399-404). https://doi. org/10.5176/2301-3710_JMComm13.46.

Bajari, A., Susilawati, S., \& Setiaman, A. (2014). Perceptions and behaviors of health communication on the poor with high and low HDI. Research on Humanities and Social Sciences, 4(4), 103-113.

Bobok, D. (2016). Selective exposure, filter bubbles and echo chambers on Facebook. Central European University Department of Political Science. Diakses dari https:// doi.org/10.1108/01443580911001797.

Clark, R. E. (1983). Reconsidering research on learning from media. Review of Educational Research, 53(4), 445-459. Diakses dari https://doi.org/https://doi. org/10.3102/00346543053004445.
Databoks. (2016). Provinsi dengan ekonomi paling kecil di Indonesia. Diakses dari https://databoks.katadata.co.id/ datapublish/2016/10/11/provinsi-denganekonomi-paling-kecil-di-indonesia.

Destrian, O., Wahyudin, U., \& Mulyana, S. (2018). Perilaku pencarian informasi pertanian melalui media online pada kelompok petani jahe. Jurnal Kajian Komunikasi, 6(1), 121-132.

Fandianta, Sanjaya, G. Y. (2013). Meningkatkan pengetahuan mahasiswa dengan memberikan fleksibilitas belajar mengajar melalui metode blended learning. Jurnal Pendidikan Kedokteran Indonesia, 2(2), $1-8$.

Flora, J. A., Maibach, E. W., \& Maccoby, N. (1989). The role of media across four levels of health promotion intervention. Annual Review of Public Health, 10(1), 181-201. Diakses dari https://doi.org/10.1146/ annurev.pu.10.050189.001145.

Friedman, C. P., \& Wyatt, J. C. (2013). Evaluation methods in medical informatics. New York: Springer Science Business and Media.

Gibbs, G. (2010). Using assessment to support student learning at using assessment to support student learning. Leeds Metropolitan University. Leeds. Diakses dari https://doi.org/10.2307/895314.

Graduated Student Instructor. (2016). Learning theories and research. teaching guide for GSIs, regents of the University of California. Barkeley.

Hardt, H. (2008). Critical communication studies. London: Routladge.

Hardum, S, E. (2019) Papua dan NTT masih kampiun dalam kemiskinan. Diakses dari https://www.beritasatu.com/ ekonomi/532895/papua-dan-ntt-masihkampiun-dalam-kemiskinan.

Hornick, R. C., Ajzen, I., \& Albarracin, D. (2009). Prediction and change of health behavior: Applying the reasoned action approach. (R. C. Hornick, I. Ajzen, \& D. Albarracin, Eds.). New Jersey: Lawrence Earlbaum Associates.

Husband, P. A., \& Hellier, E. J. (2011). Persuasive methods of communication evidence base for injury prevention.

Jehamat, L. (2018) Kemiskinan NTT dan 
korupsi ASN. Diakses dari dari https:// kupang.tribunnews.com/2018/10/07/ kemiskinan-ntt-dan-korupsi-asn.

Kosasi, S. (2014). Pembuatan sistem informasi penjualan berbasis web untuk memperluas pangsa pasar. In Prosiding SNATIF 1, Tahun 2014 (pp. 225-232). Kudus: Fakultas Teknik Universitas Maria Kudus.

KPK. (2013). Jumlah korupsi meningkat dua kali lipat. Diakses dari https://www. kpk.go.id/images/pdf/laptah/annual report 2013.pdf.

Mehraj, H. K., Bhat, A. N., \& Mehraj, H. R. (2014). Impacts of media on society: A sociological perspective. International Journal of Humanities and Social Science Invention ISSN (Online, 3(6), 2319-7722.

Morris, M., \& Ogan Christine. (1996). The Internet as mass medium. Journal of Computer Mediated Communication, 1(4). Diakses dari https://doi.org/https://doi. org/10.1111/j.1083- 6101.1996.tb00174.x.

Oberty, E. (1992). Efektifitas dalam penerapan teknologi pda (personal). Jakarta. Diakses dari https://doi.org/10.1021/jm049546c.

Parker, E. (2014). Teachers study use of bulletin boards. New Jersey.

Puschmann, C. (2015). Blogging. In Pragmatics of Computer-Mediated Communication. Diakses dari https://doi. org/10.1515/9783110214468.83.

Rakhmat, J. (2017). Metode penelitian komunikasi. Bandung: Simbiosa Rekatama.

Rakhmat, J. (2018). Psikologi komunikasi (Ed. Revisi). Bandung: Simbiosa Rekatama.

Rikanita. (2017). Pengembangan sistem informasi sekolah berbasis website di SMK negeri 1 Makassar. Universitas Negeri Makasar.

Santoso, H. (2007). Majalah dinding sebagai media untuk universitas negeri malang desember 2007. Malang.

Schramm, W. (1984). Big media, little media. Beverly Hills: Sage.

Schramm, W., \& Chu, G. C. (2004). Learning from television. Greenwich: Information Age Publishing.

Singarimbun, M., \& Effendi, S. (1989). Metode penelitian survei. Jakarta: LP3ES.

Siregar, A. (2000). Media pers dan negara: Keluar dari hegemoni. Jurnal Ilmu Sosial Dan Ilmu Politik, 4(2), 171-196.

Sudaryanto, A., \& Surakarta, U. M. (2008). Pemanfaatan tekhnologi dalam pelayanan kesehatan.JurnalBerita Ilmu Keperawatan, 1(1).

Sumintono, B., Wibowo, S., Mislan, N., \& Tiawa, D. (2012). Penggunaan teknologi informasi dan komunikasi dalam pengajaran: Survei pada guru-guru sains SMP di Indonesia. Jurnal Pengajaran MIPA, 17(1), 122-131.

Ta'meh, M. (2014). The effect of using educational websites on first year students' achievement in English grammar in Badr Community College. Journal of Emerging Trends in Educational Research and Policy Studies (JETERAPS), 5(2), 184-189.

Taillard, M. O. (2000). Persuasive communication: The case of marketing. Working Papers in Linguistics, 12 (January 2000), 145-174.

Teng, S., Khong, K. W., \& Goh, W. W. (2015). Persuasive communication: A study of major attitude-behavior theories in a social media context. Journal of Internet Commerce, 14(1), 42-64. Diakses dari https://doi.org/10.1080/15332861.2015.10 06515.

Vivian, J. (2008). Teori komunikasi massa (8th ed.). Jakarta: Kencana Prenada Media.

Wahyudin, U. \& Bajari, A. (2015). Media anti korupsi bagi generasi muda model diseminasi internal berbasis majalah dinding dan website sekolah untuk nilainilai antikorupsi bagi anak-anak SMA pada provinsi yang memiliki kejahatan korupsi tinggi. Bandung.

Zubaidah, E., \& Saptono, B. (2004). Pengelolaan majalah dinding sekolah. Jurnal Ilmiah Guru Cope, 01(8). 